\title{
Use of viminol in acute pain management after third molars extraction. Case report
}

\author{
Uso do viminol no controle da dor aguda pós-extração de terceiros molares. Relato de caso \\ Wagner Hummig ${ }^{1}$, Eduardo Grossmann²
}

DOI 10.5935/2595-0118.20180037

\section{ABSTRACT}

BACKGROUND AND OBJECTIVES: Acute postoperative pain of the third molars requires not only the ability of the dental surgeon in removing them but also the correct pharmacological control of this incidental pain that will install after the effect of the anesthetic blockade has ceased. The objective of this study was to report a case of moderate pain after third molar removal procedure, where the adverse effects of the prescribed medication were determinant for the abandonment of pharmacological treatment and consequently the maintenance of the pain.

CASE REPORT: A 22-year-old male patient, student, from the city of Curitiba, sought outpatient care for acute moderate-intensity pain after 48 hours of removal of the third molars. He was experiencing some adverse effects due to the prescription of the combination of oral codeine $(30 \mathrm{mg})$ and paracetamol $(325 \mathrm{mg})$ at every 6 hours. In view of this, we opted for the prescription of viminol hydroxybenzoate $(70 \mathrm{mg})$ orally, every 6 hours.

CONCLUSION: The prescription of the viminol hydroxybenzoate analgesic resulted in complete, rapid and effective postoperative analgesia, with excellent tolerability.

Keywords: Acute pain, Analgesia, Codeine, Pain management, Postoperative pain, Viminol.

1. Universidade Tuiuti, Curitiba, PR, Brasil.

2. Universidade Federal do Rio Grande do Sul, Porto Alegre, RS, Brasil.

Submitted in January 25, 2018.

Accepted for publication in March 20, 2018.

Conflict of interests: none - Sponsoring sources: none.

Correspondence to:

R. Coronel Corte Real,513

90630-080, Porto Alegre, RS, Brasil.

E-mail: edugdor@gmail.com

(C) Sociedade Brasileira para o Estudo da Dor

\section{RESUMO}

JUSTIFICATIVA E OBJETIVOS: A dor aguda pós-operatória de terceiros molares requer náo somente habilidade do cirurgião-dentista em removê-los, mas também no correto controle farmacológico desse quadro álgico que se instalará após o efeito do bloqueio anestésico ter cessado. $\mathrm{O}$ objetivo deste estudo foi relatar um caso de dor moderada pós-procedimento de remoção de terceiros molares, em que os efeitos adversos do fármaco prescrito foram determinantes para o abandono do tratamento farmacológico e consequentemente da manutenção da dor.

RELATO DO CASO: Paciente do sexo masculino, 22 anos, estudante, natural de Curitiba, procurou atendimento ambulatorial por queixa de dor aguda de moderada intensidade, após 48 horas da remoção dos terceiros molares. Apresentou efeitos adversos devido à prescrição da associação de codeína (30mg) e paracetamol $(325 \mathrm{mg})$ por via oral de $6 / 6$ horas. Frente a isso, optou-se pela prescriçáo de hidroxibenzoato de viminol (70mg) por via oral de $6 / 6$ horas.

CONCLUSÃO: A prescrição do analgésico hidroxibenzoato de viminol resultou em completa, rápida e eficaz analgesia pós-operatória, com excelente tolerabilidade.

Descritores: Analgesia, Codeína, Dor aguda, Dor pós-operatória, Manuseio da dor, Viminol.

\section{INTRODUCTION}

Pain is among the symptoms human beings fear the most but very often goes undertreated, not just because professionals do not mind the individual's suffering - which would be a deplorable act of torture, but because they do not know which drug may provide the correct analgesia, according to World Health Organization (WHO) ${ }^{1}$ proposed criteria.

Odontology is a field where the pain is extremely common. After different procedures, such as anesthetic block, tooth extractions, periodontal surgeries, orthognathic surgeries, and implants, among others, the acute pain will necessarily follow ${ }^{2-4}$.

Within the vast universe of pain, there is the temporary acute pain following any surgical procedure. However, inability to effectively manage pain may contribute to its chronicity ${ }^{5}$. Acute pain is characterized by an organic and biological response to an aggressive stimulus due to tissue damage secondary to trauma. As an example, third molar extractions, which release potent chemical mediators such as bradykinin, prostaglandins, P substance and interleukin, among others, which cause peripheral sensitization of the primary afferents, thus leading to painful conditions 
that also involve physical suffering and psychological wearing of the patient ${ }^{2,6,7}$. Remission is usually spontaneous and coincides with tissue lesion repair ${ }^{2,6,7}$.

It is important to stress that surgical removal of the third molars is one of the most common procedures performed worldwide in oral surgery, but adequate pain management relies entirely on the professional assisting the patient ${ }^{7}$.

In most cases, post-surgical pain control uses opioids, which require a special prescription form and are strictly controlled. They also present side effects that inhibit their use with some patients. Hydroxybenzoate viminol (HV) is a drug that can normally be prescribed, has fewer side effects and provides immediate analgesia - but is still little known among dentists. It is a powerful synthetic analgesic with central action, equipotent to codeine. A single dose of $70 \mathrm{mg} \mathrm{HV}$ corresponds to approximately $6 \mathrm{mg}$ of morphine ${ }^{8}$, giving much superior analgesia as compared to salicylates and pirazolone $e^{9}$ derivates and can be perfectly indicated for oral surgeries ${ }^{8}$. The objective of the present study was to present the HV molecule as an alternative drug to codeine in dental procedures, considering its pharmacokinetic characteristics.

\section{CASE REPORT}

A 22- years old male patient, a student from Curitiba, Paraná, presented with acute pain of moderate intensity after third molars surgery. He mentioned a previous condition of rhinitis, for which he was being treated by his ORL physician with oral dexamethasone ( $4 \mathrm{mg}$ ) every 8 hours for 10 days. It is important to stress that surgery was performed during the administration of the SAID. Therefore no other preoperative drug was prescribed. Outpatient surgical removal of the 4 third molars (Figure 1) was performed under local anesthesia, with a regional block of the inferior alveolar, lingual and buccal nerves and both vestibular and palatal terminal infiltration in the maxilla using mepivacaine at 2\% with 1:100.000 adrenaline, 2,5 vials in the lower quadrant and 1,5 vial in the upper quadrant. After the anesthetic block, an incision was performed under the left upper alveolar contour with mucoperiosteal flap, followed by osteotomy using a spherical bur on a straight handpiece, saline solution irrigation, and aspiration of the left maxillary region, next to the tooth 28 . After this extraction, we removed tooth 38 , which presented mesioangular impaction. Here, we also made an incision in the alveolar contour, osteotomy with the same drill and extraction using lowspeed cylinder bur, saline irrigation and aspiration. The same procedure was adopted on the contralateral side, starting with the maxilla and following to the mandibula. For all extractions, a straight handpiece was used.

After exodontist procedures were finished (Figure 2), we proceeded to suture with silk in 4.0 needle, making separate stitches at the extraction sites. No post-operative events were reported.

The surgeon prescribed oral administration of codeine $(30 \mathrm{mg})$ and paracetamol (325mg) every 6 hours for 5 days, recommending the application of cold compresses on the face for 24 hours and liquid diet for 3 days.

The patient was asked to return in 7 days for suture removal. However, in 48 hours post-op, the patient decided to discontinue medication due to adverse side effects, such as nausea, constipation and sickness. Without analgesic control, the orofacial pain was precipitated.

The patient was referred to us and on clinical examination, we observed a limitation of the buccal opening $(12 \mathrm{~mm})$, bilateral hematoma and swelling in the region of the mandible angle region due to the surgical act, not to mention the physical and emotional condition of the patient due to pain. To measure self-reported

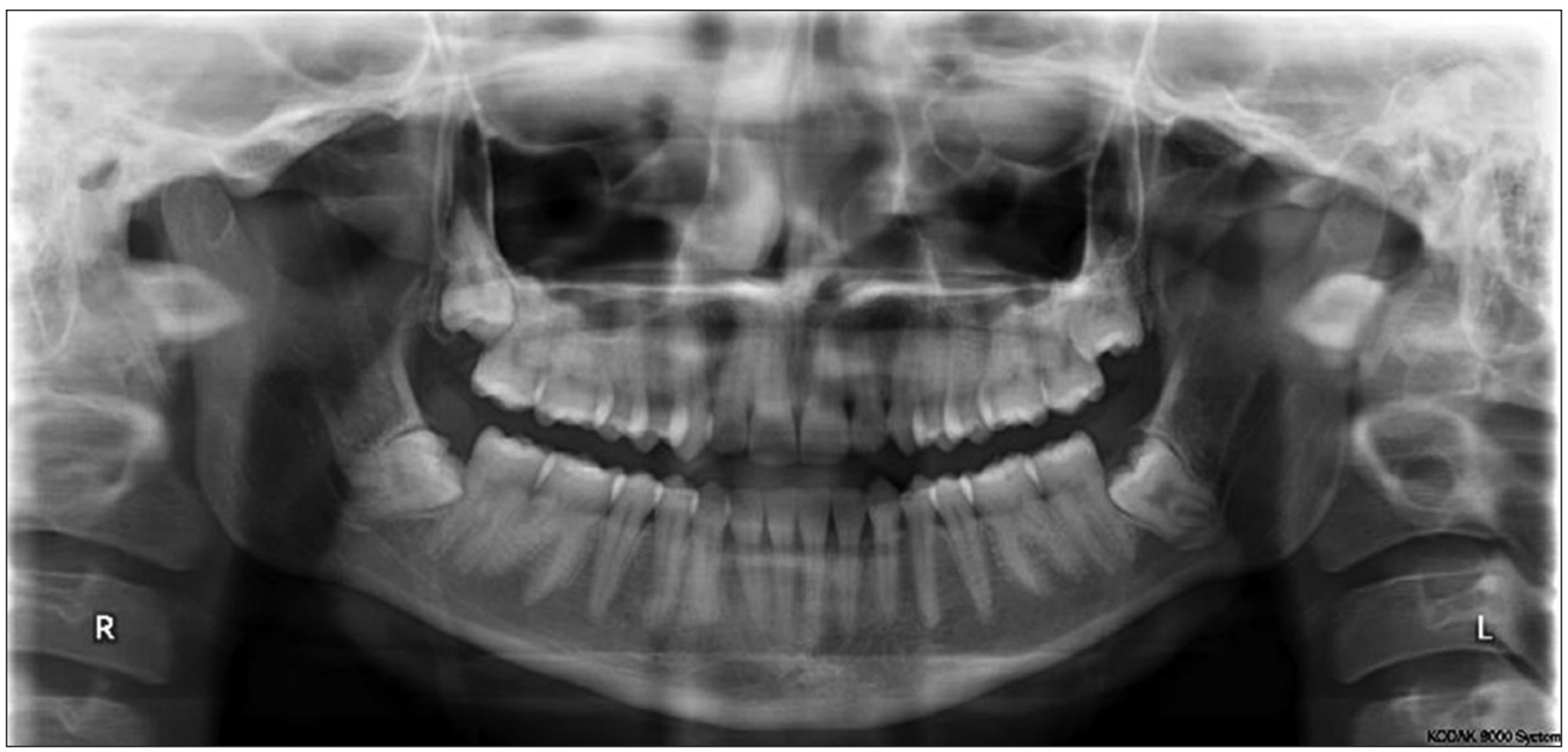

Figure 1. Initial panoramic X-ray shows the third molars in the maxilla and mandible 


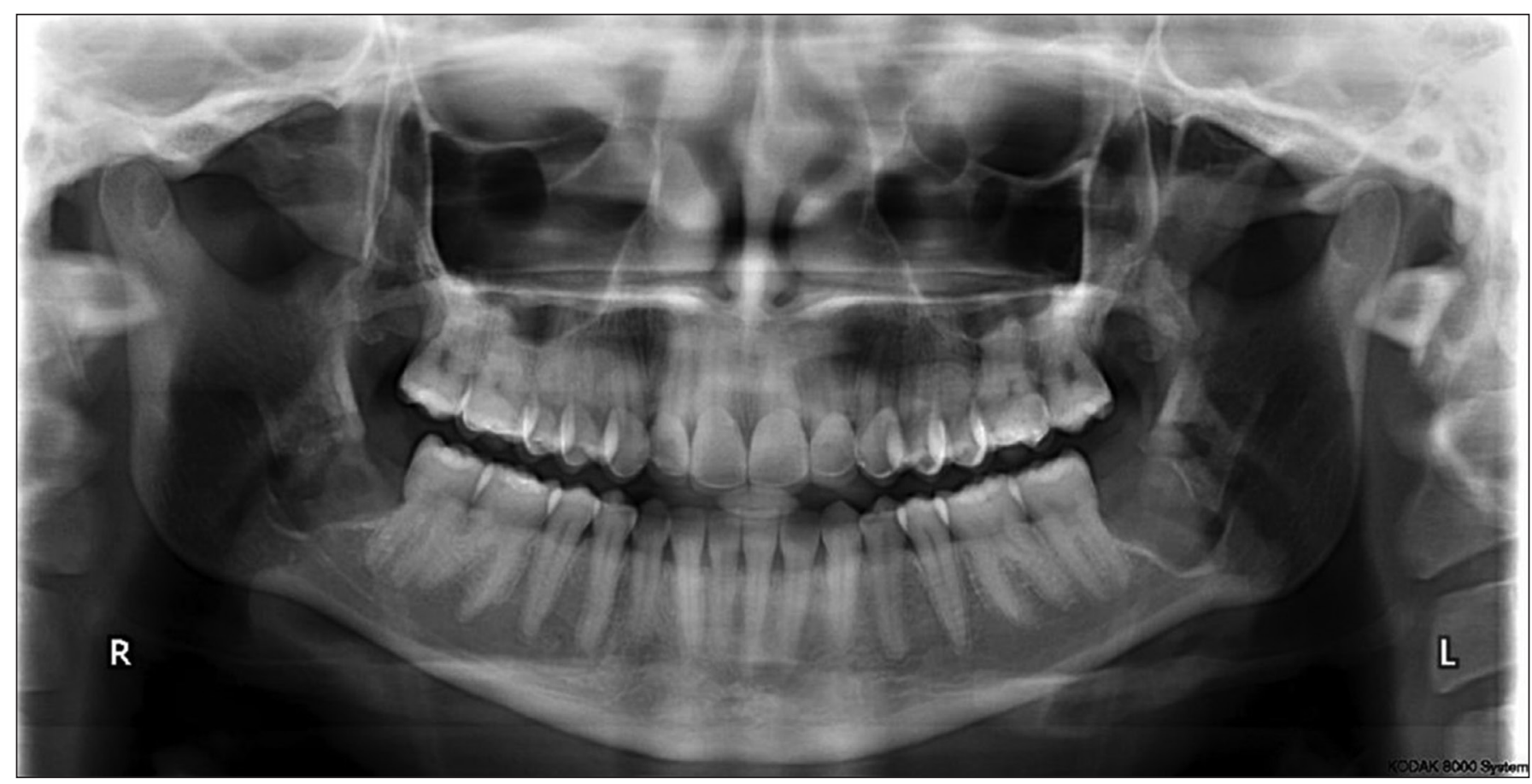

Figure 2. Final panoramic X-ray shows third molars are absent

pain, we used the visual numeric scale $(\mathrm{VNS})^{4}$ which resulted in a score of 6 (moderate intensity). Given the clinical condition and the adverse effects of codeine administration, we prescribed $\mathrm{HV}$ molecule as an alternative drug, in $70 \mathrm{mg}$ capsules presentation, to be taken every 6 hours for 7 days.

On his return visit after a week, the patient had positively responded to treatment and experienced mild painful symptoms on the extraction sites (VNS=1), with a normal buccal opening $(45 \mathrm{~mm})$. Stitches were removed, and the patient was clinically dismissed.

\section{DISCUSSION}

Measuring pain intensity with the VNS is a simple, quick and efficient method. The scale is a horizontal line with points ranging from zero to 10 , where zero means "no pain" and 10 "severe pain" - or equivalent descriptors ${ }^{4}$. On clinical examination, the patient is asked to indicate the number that corresponds to the pain he is feeling at that moment, which can range from mild to moderate to intense $e^{4}$. This scoring will help the physician's management of pain.

Codeine (3-methoxymorphina) is a mild opioid with low affinity for the opioidergic receptors and is one of the main opium-derived alkaloids, with analgesic potency ranging from 5 to $10 \%$ as compared to morphine ${ }^{10,11}$. Which means that a $30 \mathrm{mg}$ dose of codeine phosphate is equivalent to approximately $3 \mathrm{mg}$ of morphine. This natural opioid is considered a "prodrug" that must be first metabolized in the liver to become active in

morphine and morphine-6-glucuronide via the CYP2D enzyme, a member of the cytochrome $\mathrm{P} 450^{10,11}$. However, codeine capacity to metabolize codeine into active metabolites varies in the population at large $e^{10,11}$. This genetic variability, known as poly- morphism, is estimated to be present in $10 \%$ of the Caucasian, $2 \%$ of the Asian and $1 \%$ of the Arab population, who do not have the enzyme that turns codeine into morphine ${ }^{8,9}$. These patients are known to be slow metabolizers, and therefore the drug will not have the desired analgesic effect. On the other hand, fast metabolizers (or ultra-metabolizers), who represent $40 \%$ of the population in general and have elevated CYP2D6 $6^{10,11}$ enzyme, are capable of rapidly converting codeine into morphine and therefore are at increased risk of toxicity and side effects ${ }^{10,11}$, as seen the in the present clinical study. Several drugs interfere with the CYP2D6 enzyme metabolism, decreasing or increasing the codeine-morphine conversion and thus affecting its analgesic effect. Some examples are the selective serotonin reuptake inhibitors (SSRIs) such as fluoxetine and paroxetine, that reduce the analgesic effect of the drug. Rifampicin and dexamethasone increase codeine metabolism, thus increasing its toxicity ${ }^{7,11,12}$, which may have been the case here.

In this case study, the patient had voluntarily discontinued his medication because of side effects. We looked for an alternative equipotent synthetic, non-narcotic, p-ethanolamine derivative analgesic, with original differentiated chemical structure and no structural and/or chemical correlation with the natural or synthetic analgesics known to date $e^{8,9,13-15}$. The action mechanism is not fully known, but it does not present any anti-inflammatory or anti-thermal action. It acts in the subcortical region of the CNS inhibiting the perception of a painful stimulus and its processing in the superior nervous centers (the "morphine-like discriminative effect), where it loosely binds to opioidergic receptors ${ }^{8,9,13-15}$. Although it is not a classical opioid, it presents similar adverse side effects, except for mild physical addiction. However, only one case has been reported to date on this drug-induced alteration ${ }^{13}$. 
Studies have shown that HV may cause mild alterations in the waking state and motor coordination, but it does not depress the respiratory center, sympathetic reflexes or cardiorespiratory functions $s^{8,9,13-15}$, all of which have been observed in opioid user patients ${ }^{10-12,16-20}$.

The greatest advantage of this drug is not to trigger damaging effects to the gastrointestinal mucosa (even above therapeutic doses), and not to promote changes in kidney and liver functions. Its major benefit is to promote analgesia ${ }^{8,9,15}$. Due to excellent tolerability, favorable clinical response and low cost, this drug is a good option for antalgic control in orofacial surgical procedures. Also, it does not require special prescription forms ${ }^{8}$.

From the pharmacological standpoint, in clinical situations, there are no means to assess whether an individual may present previous genetic polymorphism or not in relation to codeine prodrug. But the choice of a synthetic molecule with a similar analgesic power to codeine was a determining factor for therapeutic success.

Several authors ${ }^{15,21,22}$ reported that pre-operative administration of analgesics reduce pain conditions in the immediate post-op, and suggest that preventive analgesia is an alternative for acute postoperative pain control in third molar extractions ${ }^{23}$.

The preventive approach is started even before a painful stimulus is generated, thus preventing or even decreasing subsequent pain and the onset of CNS alterations during the surgical $\mathrm{act}^{21-24}$. In this line of reasoning, a preventive approach would be to start treatment with the association of $\mathrm{HV}(70 \mathrm{mg})$ and paracetamol (750mg) 1 hour prior to surgery, to allow better bioavailability of the drug and therefore better postoperative analgesia, considering that both drugs act in synergy and promote comfort to the patient, without running the risk of genetic polymorphism.

\section{CONCLUSION}

Prescription of HV analgesic resulted in complete, fast and effective postoperative analgesia with excellent tolerability in the prescribed dose. When any abrupt adverse effects are observed in the immediate post-op, replacement of codeine should be considered. We also suggest a multimodal approach to control acute postoperative pain in third molar surgeries, taking advantage of the drugs' action mechanisms and synergy, to better control pain.

\section{REFERENCES}

1. World Health Organization (WHO). WHO analgesic ladder. www.who.int/cancer/ palliative/painladder/en/ (acesso em 18 Jan 2018).

2. Peixoto RF, Santos DH, Menezes DP, Araújo DD, Peixoto DF, Silva JS. Controle da dor pós-operatória em cirurgia oral: revisão de literatura. R Bras Ci Saúde. 2011;15(4):465-70.

3. International Association for the Study of Pain - IASP. (Acesso em 18 Jan 2018). Disponível em: www.iasp-pain.org.

4. Bottega FH, Fontana RT. A dor como quinto sinal vital: utilizaçấo da escala de avaliaçáo por enfermeiros de um hospital geral. Texto Contexto Enferm. 2010;19(2):28390 .

5. Kubricht V, Sevcik P. Chronic postsurgical pain in mixed surgical population. Does an acute pain service make a difference? Bratisl Lek Listy. 2017;118(12):746-51.

6. Chichorro JG, Porreca F, Sessle B. Mechanisms of craniofacial pain. Cephalalgia. 2017;37(7):613-26.

7. Poluha RL, Grossmann E. Treatment of postoperative pain in dental surgery after removal of third molar. Rev Dor. 2017;18(1):245-9.

8. Pos AM, Dias RA. Analgesic efficacy of different drugs. Rev Dor. 2017;18(1):102-8

9. Spilborghs $\mathrm{G}$. Avaliaçáo clínica pelo método cruzado duplo-cego da atividade do viminol nas algias vertebrais. Rev Bras Clin Terap. 1977;6(5):225-9.

10. Wiffen PJ, Knaggs R, Derry S, Cole P, Phillips T, Moore RA. Paracetamol (acetaminophen) with or without codeine or dihydrocodeine for neuropathic pain in adults. Cochrane Database Syst Rev. 2016;27(12):CD012227.

11. Straube C, Derry S, Jackson KC, Wiffen PJ, Bell RF, Strassels S, et al. Codeine, alone and with paracetamol (acetaminophen), for cancer pain. Cochrane Database Syst Rev. 2014;19(9):CD006601.

12. Cooper TE, Chen J, Wiffen PJ, Derry S, Carr DB, Aldington D, Cole P, Moore RA. Morphine for chronic neuropathic pain in adults. Cochrane Database Syst Rev. 2017;22(5):CD011669.

13. Turkiewicz G, Baltieri DA. Dependence on viminol. J Subst Use. 2007;12(4):301-5.

14. Martins AD, Silva AL. Viminol no pós-operatório de cirurgia ginecológica. J Bras Gin. 1976;82(2):375-7.

15. Neto JM, Murad JE, Monteiro SS. Psychopharmacological properties of the viminol-p-hydroxybenzoate. Rev Bras Pesqui Med Biol. 1977;10(6):361-8.

16. Wiffen PJ, Derry S, Moore RA, Stannard C, Aldington D, Cole P, et al. Buprenorphine for neuropathic pain in adults. Cochrane Database Syst Rev. 2015;30(9):CD011603.

17. Gaskell H, Moore RA, Derry S, Stannard C. Oxycodone for neuropathic pain and fibromyalgia in adults. Cochrane Database Syst Rev. 2014;23(6):CD010692.

18. McNicol ED, Ferguson MC, Schumann R. Methadone for neuropathic pain in adults. Cochrane Database Syst Rev. 2017;17(5):CD012499.

19. Derry S, Stannard C, Cole P, Wiffen PJ, Knaggs R, Aldington D, et al. Fentanyl for neuropathic pain in adults. Cochrane Database Syst Rev. 2016;11(10):CD011605.

20. Duehmke RM, Derry S, Wiffen PJ, Bell RF, Aldington D, Moore RA. Tramadol for neuropathic pain in adults. Cochrane Database Syst Rev. 2017;15(6):CD003726

21. Posso IP, Figueiredo EF, Awade R. Preemptive analgesia, preventive analgesia and protective analgesia. Rev Dor. 2017;18(1):52-5.

22. Acheampong P, Thomas SH. Determinants of hepatotoxicity after repeated supratherapeutic paracetamol ingestion: systematic review of reported cases. $\mathrm{Br} J$ Clin Pharmacol. 2016;82(4):923-31.

23. Isiordia-Espinoza MA, Pozos-Guillen A, Martinez-Rider R, Perez-Urizar J. Comparison of the analgesic efficacy of oral ketorolac versus intramuscular tramadol after third molar surgery: a parallel, double-blind, randomized, placebo-controlled clinical trial. Med Oral Patol Oral Cir Bucal. 2016;21(5):e637-43.

24. Ong CK, Seymour RA. Pathogenesis of postoperative oral surgical pain. Anesth Prog. 2003;50(1):5-17. 